\title{
DIGITALCOMMONS
}

@WAYNESTATE-

Wayne State University

Law Faculty Research Publications

Law School

$1-1-1998$

\section{Transferred Intent: An Inquiry Into the Nature of Criminal Culpability}

Anthony M. Dillof

Texas Wesleyan University, dillof@wayne.edu

\section{Recommended Citation}

Anthony M. Dillof, Transferred Intent: An Inquiry Into the Nature of Criminal Culpability, 1 Buff. Crim. L. Rev. 501 (1998).

Available at: https://digitalcommons.wayne.edu/lawfrp/140

This Article is brought to you for free and open access by the Law School at DigitalCommons@WayneState. It has been accepted for inclusion in Law

Faculty Research Publications by an authorized administrator of DigitalCommons@WayneState. 


\title{
Transferred Intent: An Inquiry into the Nature of Criminal Culpability
}

\author{
Anthony M. Dillof ${ }^{*}$
}

[A]s so often, the abnormal will throw light on the normal. J.L. Austin, A Plea for Excuses ${ }^{\dagger}$

\section{INTRODUCTION}

A central question of criminal law theory is what moral theory underlies the criminal law. For a moral theory to underlie the criminal law, it would have to imply the core prohibitions and sanction-structure of the criminal law, explain in moral terms well-established but noncore elements of the criminal law, and generate moral arguments to vindicate or reform penumbral elements. A moral theory for the criminal law thus would be in turn faithful, illuminating and inspiring.

One way to search for such a theory would be through direct inquiry. One could consider a paradigm crime and ask why it, morally speaking, should be a crime. The trouble with this approach is that it is likely to yield too many answers. There are too many moral theories that justify criminalizing, for example, $A$ 's forcible taking of $B$ 's property. Robbery is too easy a crime to be theoretically interesting. A second approach to identifying the moral basis of the criminal law is more oblique. One could consider aberrational fact patterns that have provoked conflicting moral

* Associtate Professor of Law, Texas Wesleyan University School of Law. A.B. 1981 Harvard University; J.D. 1985, Columbia University School of Law; LL.M. 1996, Columbia university School of Law. I am grateful to Douglas Husak and Scott J. Shapiro for their valuable feedback and thoughtful comments on drafts of this article.

$\dagger$ J.L. Austin, $A$ Plea for Excuses, in JUSTIFICATION AND ExCUSES IN THE Crmmnal Law 3, 7 (Michael Louis Corrado ed., 1994). 
analyses. Having resolved the conflict over such aberrational cases, one hopefully would be in a better position to understand the general case. ${ }^{1}$ To let method foreshadow subject matter, one might say that according to this latter approach, the inquiry trains its sights upon one thing (the aberrational) and ends up hitting another (the general). This article shall adopt this latter approach.

This article pursues the approach sketched above by considering the doctrine of transferred intent. This doctrine invites study because it treats a relatively aberrational fact pattern in a manner that has provoked sharp disagreement. $A$ attempts to harm $B$ and harms $C$ instead. This fact pattern is aberrational in the sense that, as a purely empirical matter, it is likely less common for $A$, attempting to harm $B$, to harm a third party, $C$, than either to succeed and harm $B$ or to fail and harm nobody at all. The fact pattern is also aberrational in the sense that the double departures from $A$ 's design seem to offset, rather than reinforce, each other: $A$ 's unexpected failure to $\operatorname{harm} B$, and unexpected harming of $C$, fulfills $A$ 's expectation of causing harm. What $A$ 's criminal liability should be has provoked conflicting judgments. Pursuant to the doctrine of transferred intent, $A$ 's intent to harm $B$ is treated as the intent to harm $C$, with liability to follow accordingly. Thus, where $A$, intending to kill $B$, kills $C, A$ may be liable for murder. Commentators have characterized the doctrine as "defect[ive]," "an arbitrary exception to normal principles," a "curious survival of the antique law, "theoretically incoherent," "[to] be rejected," "overly harsh," and having "no proper place

1. A similar approach to theorizing about the criminal law is illustrated by George Fletcher's Blackmail, The Paradigmatic Crime, 141 U. PA. L. REV. 1617 (1993).

2. Wilfred J. Ritz, Felony Murder, Transferred Intent, and the Palsgraf Doctrine in the Criminal Law, 68 WASH. \& LEE L. REV. 169, 172 (1969). 1961).

3. Glanville Willams, Crminal LaW: The General Part 134 (2d ed.

4. William L. Prosser, Transferred Intent, 45 TEx. L. REV. 650, 650 (1967).

5. Martin R. Gardner, The Mens Rea Enigma: Observations on the Role of Motive in the Criminal Law Past and Present, 1993 UTAH L. REv. 635, 712 (1993).

6. DON StuART, CANADIAN CRIMINAL ILAW 196 (1982). 
in criminal law, ${ }^{\prime 8}$ A roughly equal number of commentators, however, have approved of the doctrine and its result.' The controversy concerning transferred intent is alive. What is its basis and how should it be resolved?

I shall argue against the moral soundness of the doctrine of transferred intent. In brief, the doctrine is inconsistent with the general principle that actors should not be punished based on the unintended results of their actions (absent some other basis for culpability such as knowledge or recklessness), and harm to an unintended victim is an unintended result in the morally relevant sense. Any position to the contrary must either characterize $A$ 's intentions in an artificially abstract way or offer a shallow and unsatisfying view of the nature of punishment. Furthermore, the doctrine of transferred intent is inconsistent with the view of duty, predominant in tort law, that duties run to individuals, not to the world at large. This view is an attractive one and applies with equal force to criminal law.

Although I criticize the doctrine of transferred intent, the aim of this article is not wholly negative. Understanding the particular moral failing of the doctrine of transferred intent allows us to better understand the moral strength of the criminal law generally. This strength is its commitment to punishing for the culpable causing of harm to individuals. This article concludes that any moral theory

7. David J. Karp, Note, Causation in the Model Penal Code, 78 Colum. L. REV. 1249, 1268-69 (1978).

8. ROLIIN M. PERKINS, CRIMINAL LAAW 921 (3d ed. 1982).

9. See J.C. SMITH \& BRIAN HogaN, CRMMNAL LAW 73-75 (2d ed. 1969); Clifford Hall, A Defense of the Doctrine of Transferred Malice: Its Place in the Nigerian Criminal Code, 34 INT'L \& CoMP. L.Q. 805 (1985); Douglas N. Husak, Transferred Intent, 10 NOTRE DAME J.L. ETHICS \& PUB. POL'Y 65 (1996); Kimberly D. Kessler, Comment, The Role of Luck in the Criminal Law, 142 U. PA. L. REv. 2183, 2206-11 (1994); see also Michael N. Moore, Intentions and Mens Rea, in Issues IN CONTEMPORARY LEgaL PHIOSOPHY: THE INFLUENCE OF H.L.A. HART 245, 263-68 (Ruth Gavison ed., 1987) (underlying theory of doctrine "seems neither incoherent nor incorrect"); Lawrence Crocker, $A$ Retributive Theory of Criminal Causation, J. CONTEMP. LEGAL ISSUES 65, 81 (1994) (weakly endorsing the doctrine of transferred intent). 
of the criminal law must give a central place to this commitment.

\section{THE MEANING OF TRANSFERRED INTENT}

The doctrine of transferred intent (TI) dates back to the 16th century. ${ }^{10}$ Although no standard formulation of the doctrine exists, ${ }^{11}$ its core implications are clear. Imagine that $A$, intending to kill $B$, shoots at $B$, misses, and hits $C$, a bystander, killing her. Call this the Basic Case. Under TI, $A$ at a minimum would be liable for murder, notwithstanding the fact that he did not intend to kill $C .^{22}$ The mens rea element for murder would be deemed satisfied by $A$ 's intention to kill $B$. Absent TI, the mens rea element for murder might not be satisfied and $A$ then would be liable for only the attempted murder of $B$ and perhaps some lesser offense with respect to $C$.

A few qualifications and clarifications must be made at this point. First, although the Basic Case perhaps best illustrates TI, TI-as I shall use it-is not limited to killings. Rather, it is a general principle which permits liability for any crime involving a mens rea of intent-be it arson, assault, theft or trespass-where the actual object of the crime is not the intended object. Furthermore, although I shall mostly be interested in crimes of intent, TI seems to imply analogous doctrines of transferred knowledge, recklessness, and negligence. This generalized understanding of TI is captured in subdivisions 2.03(2)(a) and 2:03(3)(a) of the Model Penal Code. With respect to intention ("purpose" is the M.P.C.'s term) and knowledge, subdivision 2.03(2)(a) provides for liability where "the actual result differs from that designed or contemplated, as the case may be, only in

10. See Regina v. Saunders \& Archer, 2 Plowd. 473, 75 Eng. Rep. 706 (1576); Regina v. Salisbury, 1 Plowd. 100, 75 Eng. Rep. 158 (1553). See generally Prosser, supra note 4, at 652-58 (discussing origin and scope of doctrine).

11. See Husak, supra note 9 , at 66 n.8.

12. Strictly, $A$ would only be prima facie liable for murder because he might have a justification or excuse available. In my discussion, I shall assume that such defenses are unavailable. 
the respect that a different person or different property is injured or affected. ${ }^{\text {n13 }}$ Section 2.03(3)(a) of the Model Penal Code contains similar language regarding recklessness and negligence. Thus, the essence of TI is that the identity of the object of the crime does not matter. ${ }^{14}$

Second, by TI, I refer to any positive legal device for achieving liability of the type described above. Subsection 2.03(2) is one possible device for achieving such liability. Some jurisdictions accomplish the same end in other ways. With respect to murder, for example, some states establish liability for unintended victims through a statutory definition that explicitly indicates that the person killed need not be the intended victim. ${ }^{15}$ Other jurisdictions utilize malice

13. Subsection 2.03(2) of the Model Penal Code is curiously drafted. See MODEL PENAL CODE \$ 2.03(2) (Official Draft 1962). The commentaries explicitly indicate subdivision (a) is supposed to cover bystander-shooting scenarios such as the Basic Case. Id. commentary at 260 n.14. Yet in bystander-shooting cases, the actual result arguably does not differ from that designed or contemplated "only in the respect that a different person or different property is injured." The result-a death-also differs in that it occurs at a different place, and by a slightly different mode-a bullet blown off-course by the wind, say. A case in which, strictly speaking, only the person was different would be where the perpetrator was mistaken about the identity of the person who he shot. The language of subdivision (b), which merely requires that "the actual result involves the same kind of injury or harm as that design [and is not too remotel" seems to fit bystander-shootings better than that of (a). It will not do to attempt to construe subsection (a) more broadly to include bystander shootings. It might be argued that "result," as used in subdivision (a) should be read not to include place or mode of result, so that in a bystander-shooting case, the "actual result" - C's deathwould only differ from that intended-B's death-in that a different person is killed. But such a reading would allow subdivision (a) also to cover cases where the bystander is killed by modes that defy the requirement of proximate causation. If some variation in mode is allowed by subdivision (a), what is the limit? Only subdivision (b) contains language ("not too remote or accidental") to rule out cases where the proximate cause requirement is not met. This language would better appear in subdivision (1)(h) where it would have broader scope.

14. This broad statement, of course, assumes that there are no significant differences between the actual and intended victim that might affect liability such as whether the actual or intended victim enjoys heightened or diminished legal protection. For example, if the intended victim is a police officer and the actual victim is not, there would be no liability for shooting a police officer.

15. See, e.g., 720 ILL. COMP. STAT. ANN. 5/9-1 (West 1993) ("A person who kills an individual without lawful justification commits first degree murder if, in performing the acts which cause the death ... he either intends to kill or do great bodily harm to that individual or another . . . .); N.Y. PENAL LAW \& 125.25 
aforethought or depraved heart formulations, ${ }^{16}$ which will produce the same result because the intent to kill $A$ demonstrates malice or a depraved heart. The felony-murder rule also may produce the same result because attempted murder may serve as a predicate felony. I will not be concerned with the form of the mechanisms by which different jurisdictions incorporate TI. Nor will I be concerned with the question whether in a particular jurisdiction, TI, formulated as a separate supplementary doctrine, is superfluous and should thus be rejected on doctrinal grounds. ${ }^{17}$ My focus is the moral, not the doctrinal, soundness of TI.

Third, by TI, I refer to a doctrine with a strong proportionality requirement. The notion of intent being "transferred" is usually derided as fiction. Yet this fiction is a useful device for ensuring that punishment is proportional to moral culpability. If $A$ 's intent to kill $B$ is transferred to $C$, it is no longer available to support $A$ 's liability for the attempted murder of $B$. In contrast, if TI rendered $A$ liable for murdering $C$, but did not negate his liability for the attempted murder of $B, A$ 's total punishment for murder and attempted murder would be disproportionate to his culpability. $A$ should not be punished more than the standard murderer. The standard murderer would not be liable for attempted murder because murder and attempted murder are usually merged. ${ }^{18}$ In the Basic Case, there would not necessarily be a merger of offenses because the attempted

(McKinney 1989) ("A person is guilty of murder in the second degree when . . . [w] ith intent to cause the death of another person, he causes the death of such person or of a third person ....").

16. See e.g., CAL. PENAL CODE $\S 187$ (West 1986) ("Murder is the unlawful killing of a human being, or a fetus, with malice aforethought."); N.M. STAT. ANN. $\$$ 30-2-1 (Michie 1994) ("Murder in the first degree is the killing of one human being by another ... by any act greatly dangerous to the lives of others, indicating a depraved mind regardless of human life."). With respect to other crimes, such as assault, a state may have to resort to invoking a general doctrine of TI because assault is not defined as "the causing of injury to the person intended or another" or "the causing of injury with malice aforethought."

17. See Joshua Dressier, Understanding CrIminal LaW 108 (1987) (criticizing TI on these grounds).

18. See, e.g., MODEL PENAL CODE $\S 1.07(1)$. 
murder of $B$ is not technically a lesser included offense of the murder of $C$. Exposing $A$ to greater liability would be unjust because the penalty for murder is presumptively the greatest appropriate for a person who intentionally kills another. A greater penalty would produce disproportionate punishments in much the way that the felony-murder rule does. Under the felony-murder rule, a felon would be subjected to the additional liability for murder without any necessary increase in his culpability. Indeed, if under TI $A$ were also liable for attempted murder, TI would simply be a special case of the felony-murder rule, where attempted murder was allowed to serve as a predicate felony. The felony-murder rule has been roundly criticized for permitting punishment disproportionate to culpability. ${ }^{19}$ If TI permitted liability for the attempt as well as the completed offense, it would be subject to the same criticism. The assumption that under TI $A$ will not be liable for attempted murder of $B$ is not necessarily consistent with existing law. ${ }^{20}$ Nevertheless, adopting this assumption renders TI more morally defensible. Accordingly, because I believe that TI is unjust even if proportionality requirements are not violated, I shall assume that in the Basic Case there is no liability for attempted murder.

Finally, I explicitly adopt an assumption held by most commentators who have opined on the justness of TI. That assumption is that TI makes a difference in sentencing outcome. To simplify discussion, I posit that in the Basic Case, $A$ acts neither intentionally, knowingly, recklessly or negligently with respect to the death of $C .^{21} A$, we might imag-

19. See James J. Tomkovicz, The Endurance of the Felony-Murder Rule: A Study of the Forces that Shape Our Criminal Law, 51 WASH. \& LEE L. REv. 1429, 1431 n.9 (1994) (citing extensive literature critical of the felony-murder rule).

20. In People v. Scott, 927 P.2d 288, 292-94 (Cal. 1996), the only case that appears to have addressed the issue specifically, the Supreme Court of California, with one justice dissenting, held that a person could be simultaneously convicted for attempted murder and murder on facts analogous to the Basic Case.

21. If $A$ is reckless the analysis becomes more complicated. In that case, one might wonder whether the penalty for murder, pursuant to $T I$, is greater than the combined penalties for attempted murder (with respect to $B$ ) and manslaughter (with respect to $C$ ), which would occur in the absence of the doctrine. There seems 
ine, shoots at $B$ on an apparently unpopulated desert island and $C$ is standing behind a wall of bushes near $B$ when she is shot. Thus, without TI, $A$ would be liable for only the attempted murder of $B$; with TI, $A$ is liable for murder only. For TI to have any bite, there must be a difference between the sentences that might be imposed for murder and attempted murder. A greater potential sentence for murder than attempted murder is a feature of most criminal codes. ${ }^{22}$ For most of my discussion, I will assume that the greater punishment for completed offenses is a deeply imbedded feature of the criminal law. Thus, the central issue of this inquiry may be stated as: Where the criminal law systematically treats completed offenses more harshly than unsuccessful attempts, should TI be employed so that an otherwise unsuccessful attempt is treated like a completed offense?

\section{A VERY BRIEF HISTORY OF CRIMINAL CULPABILITY}

The debate concerning the justness of TI may usefully be set in a historical context. As discussed below, the history of the development of culpability in law displays in rough outline a movement toward requiring an ever tighter nexus between actual and intended results.

In the beginning, criminal law cared little about intentions. The notion of mens rea, or "guilty mind," did not enter law until the early thirteenth century..$^{23}$ Prior to this time, strict liability was often the rule, and so any intention

to be no necessary reason why this should be so. In cases where it is not, applying TI thus would result in a lesser penalty. If, however, $A$ 's recklessness with respect to $C$ is simultaneously "transferred" to $B$ so that $A$ is liable for murder plus reckless endangerment, a good argument can be made that this combination will produce a greater combined penalty. It takes only rudimentary algebra to demonstrate that, if desert is a proportional function of culpability and harm, greater aggregate desert will obtain if the higher culpability is applied to the greater harm and the lesser culpability to the lesser harm than if the higher culpability is applied to the lesser harm and the lesser culpability is applied to the greater harm.

22. See 2 WAYNE R. LaFAVE \& AUSTIN W. SCOTT, JR., SUBSTANTTVE CRIMnAL LAW 59-60 (1986).

23. See Gardner, supra note 5, at 642. 
or no intention would do. ${ }^{24}$ This severe standard may well have rested on practical concerns of avoiding private vendettas, rather than on a developed moral theory according to which intention was irrelevant..$^{25}$ Nevertheless, it suggests that intention, compared to injury, was a latecomer to the law.

The jurist most associated with the introduction of mens rea into the criminal law is Henry Bracton. A cleric as well as a judge, Bracton wrote, "a crime is not committed unless the intention to injure exists. ${ }^{226}$ The requisite intention to injure, however, was not defined with great care. It appears that any fault on the part of the actor would be sufficient. ${ }^{27}$ Accordingly, Bracton has been understood as adopting the canonist doctrine of versanti in re illicitae imputantur omnia guae sequntur ox delicto: one acting unlawfully is held responsible for all the consequences of his conduct. ${ }^{28}$ The consequences of such a doctrine may be harsh, as the harm for which an actor is held liable may be disproportionate to the actor's moral culpability. Bracton's versanti principle thus exemplifies what Professor Michael Moore has described as "a kind of crude forfeiture theory, whereby once a defendant has crossed some threshold of culpability we should not care about making any further discriminations in degree of culpability." The vestiges of such an approach

24. Id. at $642-43,652$ n.70 (finding consensus of scholars that primitive English law operated on essentially a strict liability basis). According to Professor Sayre, "What the recorded fragments of early law seem to show is that a criminal intent was not always essential for criminality and many malefactors were convicted on proof of causation without proof of any intent to harm." Francis E. Sayre, Mens Rea, 45 HARV. L. REV. 974, 982 (1932). Professor Sayre, however, notes that "at least with respect to some crimes," intent was relevant. Id.

25. Gardner, supra note 5, at 651.

26. HENRY D. BRACTON, ON THE LAW AND CUSTOMS OF ENGLAND 384 (Samuel E. Thorne trans., 1968)

27. See Gardner, supra note 5, at 655-56 (discussing Bracton's example of a master who flogs his pupil "improperly" and so is liable for homicide even if the pupil's death was unintended).

28. Stanislaw Frankowski, Mens Rea and Punishment in England: In Search of Interdependence of the Two Basic Components of Criminal Liability (A Historical Perspective), 63 U. DET. L. REV. 393, 412 (1986).

29. Moore, supra note 9 , at 266. 
may be found in today's felony-murder rule. According to this rule, once an actor has "crossed the line" by committing a felony, he is thereby liable for murder if his action has resulted in a death. Bracton's versanti principle would be functionally equivalent to a "felony-felony" rule.

A pair of 19th century cases established a significant tightening of the requisite nexus between evil intent and harm caused. In Regina $v$. Pembliton, the defendant was charged with malicious damage to property when a stone he had thrown at another person struck and broke a window. ${ }^{30}$ In Regina $v$. Faulkner, the defendant was charged with arson for causing a fire that destroyed a ship in the course of trying to steal property from it. ${ }^{31}$ In each case, the defendant had a criminally wrongful intent. Yet in each case, the court held that the intention was not sufficient to establish liability for the charged offense. Rather than accepting any improper intention, the courts required that the defendant have a guilty mind with respect to the type of harm prohibited.

The next step in tightening the nexus between intention and result would be to require the intention to cause not merely the same type of harm as that intended, but the same instance of harm as that intended. This in fact is the approach taken in German and Nigerian law, which reject $\mathrm{TI}^{32}$ The question is whether this further step can be morally justified.

\section{THE MERITS OF TRANSFERRED INTENT}

\section{A. Accidents, Mistakes and Concurrence}

Perhaps the most basic criticism of TI is that it establishes an inappropriately high level of liability for occur-

30. Regina v. Pembliton, 2 L.R.-Cr. Cas. Res. 119, 12 Cox C.C. 607 (1874).

31. Regina v. Faulkner, [1877] I.R. 8, 13 Cox C.C. 550 (Ireland).

32. See HANS-HEINRICH JESCHECK, LEHRBUCH DES STRAFRECHTS: ALLGEMEINER TEIL 281 n.74 (4th ed. 1988) (discussing majority and minority positions); NIGERIAN CRIM. CODE § 24 (1990). See also CYPRIAN O. OKONKWO \& MICHAEL E. NAISH, CRIMINAL LAW IN NIGERIA 52-53, 80-84 (2d ed. 1980); but cf. Hall, supra note 9 (arguing issue open and TI should be accepted). 
rences that are accidental. According to a leading treatise on Canadian criminal law, "[i]t is submitted that the doctrine of transferred [intent] should be rejected ... The danger is that we might end up punishing a mere accident." ${ }^{.33}$ It seems clear that in the Basic Case, we would say that $C$ was killed "by accident" or "accidentally" despite the fact that $A$ was trying to kill $B$. There is no awkwardness in saying, "while in the process of trying to kill $B, A$ accidentally killed $C$." It is less clear, however, how this fact entails that $A$ should not be treated as harshly a murderer. Accidents do not wear their normative implications on their sleeve. This section seeks to develop a fuller argument for the claim that $A$ 's punishment for causing $C$ 's death should be decreased because "it was (only) an accident."

\section{How Accidents Exculpate}

Claims of accident may be used to deny, or at least diminish, responsibility for an occurrence. Claims of accident may accomplish this in a variety of ways. Sometimes lack of agency is the basis of the denial. Imagine that Sally is cleaning her revolver when a sudden crack of thunder startles her, causing her hand to tighten on the trigger, the revolver to discharge, and Tom's window to be thereby shattered. In this case, Sally may argue that her shooting out of the window was merely an accident; she shouldn't be blamed because the thunder caused her to squeeze the trigger. In law, the requirement of a voluntary act might be invoked. ${ }^{34}$ Clearly, the Basic Case does not involve an accident in this sense of the word. Or suppose that Mike shoots at an elephant, the bullet misses, and through an unlikely set of ricochets, the bullet hits Rita who was standing behind Mike. Here too, Mike, to avoid blame, might say that Rita's injury was an accident. In law, we would explain that Mike should not be held liable for shooting Rita on the ground that the manner in which it occurred was so freak-

33. STUART, supra note 6, at 196-97.

34. See, e.g., MODEL PENAL CODE § 2.01. 
ish that there was no proximate causation. ${ }^{35}$ The Basic Case, however, does not involve an accident in this sense of accident either. Imagine a variation on the Basic Case-the Risk Case-in which the only difference is that $A$ is informed that due to normal wind conditions, there is a substantial risk that his shot will miss $B$ and hit a bystander, $C$. $A$ shoots at $B$, there is a minor gust of wind, and $C$ is hit and killed. In the Risk Case, even the critic of TI, who believes $A$ should be punished less than a murderer, will want to hold $A$ liable for manslaughter with respect to $C$. The gust of wind would not be considered an intervening cause precluding liability. Thus, in asserting that $C$ 's death is a mere accident that should not be grounds for treating $A$ as a murderer, the critic of TI is not alleging an insufficient causal connection between $A$ 's firing and $C$ 's death.

The sense of accident that $I$ think best fits the Basic Case is accident as an unintended result. Where a result diverges from that intended, we often describe the actual result as an accident. We might, for example, imagine $A$ subsequently explaining to the police, "It was an accidentI didn't mean to shoot $C$." Intentions are undeniably a basis for ascribing moral responsibility and blame. As note earlier, in the Basic Case, $A$ is assumed not to have acted knowingly, recklessly or negligently with respect to $A$ 's death. Having eliminated intentionality, the fourth major basis of moral culpability, the critic of TI may conclude that $C$ death is not relevant to determining what punishment $A$ deserves.

2. Accidents v. Mistakes

The critic of TI who points out that $C$ 's death was accidental, however, cannot rest with the claim that $A$ did not intend to kill $C$. Sometimes an actor clearly should be liable

35. It might also be said that $C_{s}$ death occurred by chance, rather than by accident. See D.W. Theobold, Accident and Chance, 45 PHIL. 106 (1970) (distinguishing accidental and chance occurrences). See also DoNALD DAVIDSON, Freedom to Act, in ESSAYS ON ACTIONS AND EVENTS 78 (1980) (claiming that where lack of proximity, agent did not cause result intentionally). 
for murder despite not having intended to kill the person whom she did. Consider the Mistake Case. $A$ mistakenly believes that $B$ is the person standing on the corner; $A$ shoots at this person, killing him; the person who was standing on the corner, however, turns out to be $C$. Even those who reject TI are not tempted to hold that $A$ should not be liable for murder on the ground that he intended to kill $B$, not kill $C .^{36}$ The distinction between accidents and mistakes is a familiar one. ${ }^{37}$ Nevertheless, the moral significance of the distinction is not obvious. Both claims of accident and mistake may sometimes excuse or mitigate blame. Furthermore, from a more detached perspective, the distinction between accidents and mistakes may seem superficial: An accident may be described as simply an occurrence based on the mistaken belief that the conditions causing the accident would not obtain; a mistake may be described as simply the result of an accident that occurs in the process of belief formation. A central challenge for any critic of TI, therefore, is to distinguish between unintended results that arise through accident, as in the Basic Case, which allegedly exculpate, and unintended results that arise through mistake, as in the Mistake Case, which are not at all exculpatory. ${ }^{38}$

The moral difference between accidents and mistakes may be seen by stepping back for a moment to attend to the manner in which inculpation occurs. An actor, it may be argued, is prima facie responsible for a harmful consequence of his action when the consequence is intended. ${ }^{39}$ In

36. See JESCHECK, supra note 32, at 281.

37. See Austin, supre note $\nmid$, at 28 n.2.

38. This need to distinguish cases of accident and mistake is not always appreciated. In Karp, supra note 7, the author implies that an actor's achieving of his "basic objective" is a prerequisite for liability. Id. at 1270 . Whether an actor who through mistake kills a person she did not intend should be able to avoid liability based on her failure to achieve her "basic objective" is not discussed.

39. See Moore, supra note 9, at 268 n.46. Moore writes: "The concurrence principle holds that [for there to be liability based on intentions] the defendant must have caused a particular harm that instantiates the type of harm intended." As I will argue, see section IV.A.3 supra, this principle is best understood as requiring the instantiation of the type of harm strictly intended. 
the context of criminal law, Professor Michael Moore has called this principle of liability the Concurrence Principle because intention and result are required to concur. ${ }^{* 0}$ The Concurrence Principle may seem implausibly narrow. After all, there are many examples of cases involving divergent intentions and results where we believe the actor should be held as accountable as if there were no divergence. Here are two examples: (1) Unintended Manner of Injury Case: $A$ intends to kill $B$ by shooting him in the head, but because of a gust of wind, shoots him in the heart killing him; (2) Unintended Degree of Injury Case: $A$ intending to kill $B$ by shooting him merely wounds him. In these cases, we believe $A$ should be held as responsible for killing $B$ and wounding $B$ as if there had been no divergence between actual and intended results. To accommodate these cases, the Concurrence Principle should not be construed so narrowly that it establishes liability only where all aspects of a consequence are intended. Rather, it should be construed as establishing liability for any aspects of a consequence that are intended. For example, in the Unintended Manner of Injury Case, although $A$ did not intent to shoot $B$ in the heart, he did intend to kill him, which in fact occurred. Thus, pursuant to the Concurrence Principle, $A$ should be held liable for killing $B$, even if $A$ should not be liable for shooting $B$ in the heart. Likewise, in the Unintended Degree of Injury Case, although $A$ did not intend to wound $B$, he intended to injure $B$, which occurred, and so should be liable for assault.

Exculpatory pleas of accident and exculpatory pleas of mistake respond to the Concurrence Principle in different ways. In the case of mistakes, the actor is admitting the existence of the concurrence, but distancing himself from the concurring intention on the ground that it rested upon a mistaken belief that was reasonable to hold and that rea-

40. Moore's Concurrence Principle should not be confused with another criminal law principle with the same name. According to this principle, the culpable mental state of the actor defendant must have actuated the physical conduct the actor is charged with performing. See LAFAVE \& SCOTT, supra note 22, at 377 . 
sonably generated the intention at issue. For example, the Police Officer might say,

Yes, I shot him. It wasn't an accident. I saw him point at me what I believed to be a gun and, on that basis, decided to shoot him. It seems I was mistaken; it was a water pistol. But if you saw that shape pointed at you, you would have tried to shoot him yourself.

In the Mistake Case, the Concurrence Principle is satisfied because $A$ both intended to kill the person standing on the corner and did kill the person standing on the corner. The assertion of mistake is not exculpatory because $A$ cannot distance himself from the intention to shoot the person on the corner. Although it might have been reasonable to believe that $B$ was the person on the corner, it was not reasonable to form the intention to kill that person based on that belief. In contrast, in the case of accidents, the actor is denying that he ever held the intention that is alleged to concur with the result. Thus, the Police Officer might say, "It was an accident. I never intended to shoot the bystander I hit. I just aimed poorly at the fleeing felon." Likewise, in the Basic Case, $A$ can plead that not only did he not intend to shoot $C$, he did not intend to shoot the person who was located where $B$ was. Thus, the critic of TI is able to explain why $A$ should not be held accountable for $C$ 's death even if $A$ in the Mistake Case should be. In the Basic Case, there is no concurrence between intention and result; in the Mistake Case, there is.

\section{Alternative Descriptions of Intentions}

The previous section demonstrated that in determining culpability, it is important how a result is described. In the Mistake Case, only when $C$ 's death was described as "the death of the man on the corner" could the Concurrence Principle be successfully invoked against $A$. The question naturally arises whether in the Basic Case, $C$ 's death can be described in a manner that would create liability under the Concurrence Principle. It is sometimes argued that in the 
Basic Case, $A$ should be treated as harshly as a murderer because $A$ intended to "kill someone" and did "kill someone." ${ }^{\text {"1 }}$ Thus (the argument goes) there is the requisite concurrence between that which was intended and that which occurred.

At this point, it is helpful to distinguish between two senses of intention. We may be said to generally believe the logical consequences of our beliefs (assuming we are rational and the matter involved is not too complicated). Thus if $\mathrm{Al}$ believes that the Mets will win the World Series in 1999, he believes that either the Mets or the Yankees will win the series in 1999. ( $P$ implies $(P$ or $Q)$ ). Analogously, we may be said to intend the logical consequences of our intentions. ${ }^{2}$ Imagine that $\mathrm{Al}$ is thirsty, intends to drink some water, sees a glass of water nearby, intends to reach it, reaches for it, grasps it and drinks it. Al of course believes that in every world in which he grasps the glass, he either grasps the glass of water or eats a cracker. Thus, in intending to bring about a world in which he grasps the glass of water, $\mathrm{Al}$ intends to bring about a world in which he either grasps a glass of water or eats a cracker. (All worlds in the first group are worlds in the latter group). We may say $\mathrm{Al}$ "derivatively intends" that he grasps a glass of water or eats a cracker, because this intention derives from the logically prior intention to grasp a glass of water. The ascription of a derivative intention to a person is a pretty trivial matter. Indeed, by the previous line of reasoning, we could have equally well ascribed to $\mathrm{Al}$ the intention to grasp the glass of water or stand on his head, or even the intention to grasp a glass of water and not eat a cracker. In contrast, the

41. See Hall, supra note 9, at 810 ("If the accused intended to kill one person but killed another, then his general objective has been achieved since he intended to kill and did kill"); Crim. L. Comm'rs, 4th Rep't, PARL. PAP. xix-254 (1839) ("[h]e intended to kill and did kill; whether, therefore, the crime be estimated by the intention or the result, its magnitude cannot be affected by the consideration that the mischief did not light where it was intended").

42. JoHN R. SEARLE, INTENTIONALITY: AN ESSAY IN THE PHILOSOPHY OF MND 79-83, 103 (1983) (comparing intentions and beliefs and discussing whether we intend the consequences of our intentions). 
intention to grasp a glass of water may be called a "strict intention." This intention is not ascribable to $\mathrm{Al}$ merely because it is a logical consequence of another of Al's intentions. Rather, this is a core intention that guided Al's action, that caused him to reach out his hand for the glass, and that explained his behavior. It is this intention which, if $\mathrm{Al}$ were asked to write out the chain of practical reasoning that led him to extend his hand, would be among the links in the chain. The object of strict intentions need not be intrinsically desired. Although Al strictly intended to grasp the glass, grasping the glass was only desired as a means to Al's ultimate end of satisfying his thirst. ${ }^{43}$

Returning to the Basic Case, we see that $A$ 's intention to kill a person is a derivative intention. It may be ascribed to $A$ merely because in intending to kill $B, A$ perforce intends to kill a person. The intention to kill a person, however, neither guides $A$ 's action, explains his behavior, nor caused $A$ to shoot at the person on the corner. If the intention to kill a person had been a strict intention, $A$ would likely have acted very differently. Imagine $A$ is a psychotic killer who simply wants to kill somebody or a would-be gang member who must kill someone (it doesn't matter who) to complete his initiation. In these cases where $A$ strictly intends to kill someone, $A$ might have shot the first person he saw that day, or shot into a crowd, or waited until he encountered a particularly vulnerable person. In contrast, in the Mistake Case, the intention to shoot the person on the corner is a strict intention. It explains why $A$ positioned himself with a view of the cormer, aimed his rifle as he did, and explains his feeling of satisfaction as he sees the person on the corner crumple.4 Thus, we may generally say: In cases of acci-

43. This usage of "strict intention" is consistent with the general use of "intention" and the criminal law's use. A contract killer, for example, will be held liable for intentionally killing another even if the only reason for the killing was to collect a fee.

44. There are alternative, albeit slightly less intuitive, ways of describing A's intentions such that the Concurrence Principle is satisfied. Imagine that $A$ believes that $B$ is left-handed and that $C, A^{\prime}$ 's actual victim, happens to be lefthanded. In that case, one might correctly say that $A$ intends to kill a left-handed 
dent, none of an actor's strict intentions are realized; in cases of mistake, although the actor's intrinsic intentions may be defeated, at least some strict intentions, in particular those based on the mistaken belief, will be realized.

I believe that the Concurrence Principle would be morally more sound if construed to require concurrence between results and only strict intentions. It is not enough that an intention can be ascribed to an actor, as derivative intentions can trivially. Insofar as we are rational beings who actually engage in practical reasoning, strict intentions play an essential role in our lives. In contrast to derivative intentions, we are generally aware of our strict intentions and so consciously embrace them. We may not think in terms of acting pursuant to various abstract characterizations of our intentions, such as the intention to kill "a person." Furthermore, strict intentions, as opposed to derivative ones, play a significant causal role in bringing about the harmful result. Consider the case of the Nephew who intends to murder his Uncle and while driving to his Uncle's house to carry out his plan, accidentally hits and kills his Uncle. In this case, there is a concurrence of intention and result, but we are not inclined to treat the Nephew as a murderer. ${ }^{45}$ Although the Nephew intended to kill his Uncle, this intention did not bring about the Uncle's death in the manner necessary for the Nephew to be held fully accountable. Similarly, in the Basic Case, the derivative intent to kill a person, although realized, did not bring about the death of a person in the right way. Thus, in the Basic

person and that a left-handed person was killed. The intention to kill a lefthanded person is not a logically derivative intention of the strict intention either to kill $B$ or to kill the person on the corner. Yet the intention to kill a left-handed person fails to play the role in $A$ 's practical reasoning that the intentions to kill $B$ or kill the person on the corner do. In Professor Fletcher's terms, the intention to shoot a left-handed person is not a "rational motivation" of $A$ 's acts and so is not relevant for determining liability. Cf. GEORGE P. FLetcher, RETHINkING CRIMINAL LAW 160-66 (1978) (proposing a "rational motivation" test for determining what beliefs about the attendant circumstances of an act should be incorporated into the description of what the actor is attempting to do).

45. See LaFAVE \& SCOTT, supre note 22, at 380 (analyzing the hypothetical above in a similar way). 
Case, there is a failure of causation: not a lack of proximate causation between $A$ 's act and $B$ 's death, but $A$ 's intentions and $B$ 's death.

Relying on derivative intentions may lead to results that are inconsistent with law and our intuitions. A's intention may be characterized even more abstractly than the intention to kill a person. In shooting to kill $B, A$, it may be said, (derivatively) intended to cause "some consequences in the world." In the School Children Case, A's bullet, after hitting $C$, continues and hits and kills a wild bear that is just about to kill three school children. The saving of the three children is derivatively intended by $A$, because it is a consequence of his act and $A$ (derivatively) intended his act to have consequences. Allowing concurrence based on derivative intentions, $A$ morally should be held as responsible for the saving of the school children as for the death of $C .^{45} \mathrm{Le}-$ gally, $A$ should be able to raise justification as a defense because the social benefits he (derivatively) intended and caused outweighed the social harm. This result, however, conflicts with the law of most jurisdictions. In most jurisdictions, the fortuitous saving of the school children would not be counted in $A$ 's favor because it was unintended. ${ }^{47}$

46. I put to the side the question whether the saving of the school children is too remote a result of $A$ 's act to be credited to him. I assume that slightly more complicated scenarios could be crafted in which proximate cause problems do not arise for accidentally produced benefits.

47. Cf. MODEL PENAL CODE $\S \S 3.02-3.08$ (requiring at least belief that the justifying circumstances exist in order to qualify for various justification defenses); LAFAVE \& SCOTT, supra note 22, at 635 ("To have the defense of necessity, the defendant must have acted with the intention of avoiding the greater harm."). For an illuminating debate concerning the moral and practical soundness of current justification law in this regard, see Paul Robinson, $A$ Theory of Justification: Societal Harm as Prerequisite to Criminal Liability, 23 UCLA L. REv. 266 (1975); George P. Fletcher, The Right Deed for the Wrong Reason: A Reply to Mr. Robinson, 23 UCLA L. REV. 293 (1975); Paul H. Robinson, Competing Theories of Justifications: Deeds v. Reasons, in HARM AND CULPABILITY (A.P. Simester \& A.T.H. Smith eds., 1996); GEORge P. FueTCHER, THE BASIC CONCEPTS OF CRMINAL LAW (forthcoming 1998). 


\section{B. Punishment Without Concurrence}

Professor Husak has presented the most thorough and thoughtful analysis to date of the moral implications of TI. In his article, Transferred Intent, ${ }^{48}$ Husak does not undertake a lengthy defense of the justness of TI, partly assuming the existence of a consensus in its favor. ${ }^{49}$ Rather, his project is to present a rationale for TI that does not depend on the empty metaphor of "transference of intent." Both Husak's shorter defense of the merits of the doctrine and his rationale for it (which indirectly bolsters the doctrine by providing a theoretical foundation for it) merit discussion. Husak's theory of TI is of particular interest because it appears to dispense with the requirement of concurrence of intended and actual results. Having argued for a particular interpretation of the Concurrence Principle, in this section I attempt to justify the requirement of concurrence more generally.

\section{Husak's Defense of TI}

Husak begins by considering the "intuitive purist"-the person who does not believe that $A$ should receive the punishment for murder. Husak admits the position of the intuitive purist is coherent and plausible. ${ }^{50}$ Nevertheless, he believes the following "hard case" may persuade some purists that the result produced by TI is just:

Suppose that Arthur intends to kill two victims. He is amazed at his good fortune when he sees both his intended victims in close proximity. He carefully aims at each, and quickly fires two bullets. Both victims drop dead. The subsequent autopsy reveals that the bullet he aimed at his first intended victim hit and killed the second victim instead, and the bullet

48. Husak, supra note 9.

49. See id. at 71. Although TI is well-established as a matter of positive law, there is no consensus on its merits in the academic community. See notes 1-9 supra.

50. Husak, supra note 9, at 70. 
he aimed at his second victim hit and killed the first victim instead. ${ }^{51}$

Husak states that one who rejects TI would have to conclude that Arthur is not guilty of murder-a result with which he doubts anyone is pleased.

Husak's hard case presents a tempting scenario for the application of TI. This temptation, however, should be resisted. Husak's hard case seems to support TI only because it is unclear how the relevant events should be characterized. If the scenario should be characterized as Arthur's engaging in a single action (firing at victim-1 and victim-2) based on a single intention ("cause the deaths of victim-1 and victim-2"), the opponent of TI can agree that Arthur should be punished like a double murderer. TI would not be needed. There would be strict concurrence between intent ("cause the deaths of victim-1 and victim-2") and result (deaths of victim-1 and victim-2). Just as in the Unintended Manner of Injury Case, the minor variation in how the result was accomplished would not be significant. The plausibility of this single-act/single-result characterization accounts for the temptation to impose on $\mathrm{A}$ the punishment for double murder.

Husak, however, may respond by stipulating that Arthur has distinct intentions ("cause death of victim- 1 " and "cause death of victim-2") and has engaged in distinct actions (firing at victim-1 and firing at victim-2). ${ }^{52}$ Pursuant to this stipulation, the opponent of TI must concede that there is no double murder. So stipulated, however, Husak's hard case loses its force. Where it is clear that two intentions are involved, the intuition that the actor should be punished like a double murderer fades. Consider the Distinct Intentions Case. Arthur sees Bob, shoots at him and misses, and the bullet kills Charlie. Next year, Arthur, unaware that

51. Id. at 71.

52. Such a stipulation could not be attacked as empty. The criminal law must have an implicit theory of intention individuation in order to decide such questions as how many counts of attempted murder should be charged to a person who shoots three multi-bullet bursts from an automatic weapon. 
Charlie has died, decides to kill Charlie and sends a letter bomb to his former house. Bob happens to be living at Charlie's former house and is killed by the bomb. Husak's hard case, understood as involving two intentions, and my Distinct Intentions Case are structurally identical. The only difference is that in the Distinct Intentions Case, the appearance of a single action based on a single intention resulting in a single result is eliminated by increasing the time and distance between the relevant events. I find that once this appearance has been removed, my intuitions regarding whether Arthur should receive the punishment for double murder return to their original anti-TI position: Arthur, in the Distinct Intentions Case and in Husak's hard case (construed to involve two intentions), deserves to be punished only for two unsuccessful attempts and perhaps two instances of manslaughter.

A further counter-hypothetical to Husak's may be imagined. In this hypothetical, Andre's target practice is interrupted by his noticing that his sworn enemy, Bret, has wandered within range and is standing in close proximity to the target. In quick succession, Andre fires off one shot at Bret and, resuming his practice, fires one shot at the target. Bret is killed and the center of the target is hit. A subsequent autopsy of Bret reveals what the astute reader has likely anticipated: that the first shot missed Bret and struck the target and the second shot missed the target and struck Bret. In this case, I feel confident that Andre should be held liable for attempted murder (via his first shot) and perhaps manslaughter (via his second shot), but not murder. The first shot failed to cause the death of a human being; the second was not intended to kill. If we are willing to let the autopsy results persuade us in this case that there was no murder, but merely (from Andre's perspective) a lucky bull's-eye and a lucky killing, should we not grant that Husak's hypothetical is no more than a case of a double lucky killing, not a double murdèr? 
2. The Principle of Proportionate Sentencing

Husak does not seek to offer an account of the Basic Case according to which $A$ intentionally caused the death of another person. Indeed, Husak in explaining TI, does not attempt to show that $A$ is, in any significant sense, a murderer. Rather, the key to Husak's theory of TI is that $A$, while not a murderer, nevertheless deserves a punishment as harsh as that a murder deserves. ${ }^{53}$ To reach this conclusion, Husak invokes what he calls the principle of proportionate punishment. According to this principle, the harshness of the punishment that is due a person is a function of two variables: harm and culpability. If two people act with the same culpability and proximately cause the same amount of harm, they have committed equally serious crimes and deserve the same punishment. Thus, because $A$, like a murderer, (1) proximately caused the death of a person, and (2) intended to cause the death of a person, he deserves the same punishment as a murderer. ${ }^{54}$ For Husak, the principle of proportionate sentencing provides a theoretical basis for TI because it generates the results implied by TI.

The principle of proportionate sentences, upon which Husak's theory of TI rests, suffers from two flaws. The first is that the principle is too broad. The principle of proportionate sentences contains no requirement that the harm caused and the harm intended be of the same type. There seems no reason to reject the possibility that harms of different types may be equally severe. For example, shooting someone in the leg might be as harmful as burning a building. Imagine then that Sam, in attempting to shoot Don in the leg, misses and hits a hidden gas main causing a building to explode; Sid successfully shoots Dan in the leg. According to the principle of proportionate sentences, Sam should receive the same sentence punishment as Sid who is successful. Or, to take a more extreme case, imagine that

53. Husak, supra note 9 , at 87.

54. Id. at 91-92. 
Joe has sex with a woman he believes to be his sister in an apartment she tells him she owns. In fact, she is not his sister and they have entered the apartment without the permission of the true owner. ${ }^{55}$ If the harm associated with incest is equal to that of trespass, then according to the principle of proportionate sentencing, Joe, who has acted culpably and thereby caused harm, should receive the punishment for either incest or trespass even though he committed neither. This is counter-intuitive. The scenario seems to involve merely the fortuitous overlap of the mens rea for attempted incest and the actus reus of trespass. Merely because they are causally connected does not make that harm and culpability jell into a single moral wrong. The limitation on transferring intent within a type of harm is also consistent with existing law. ${ }^{56}$

The principle of proportionate sentencing would also be too broad if it does not require that the harm is caused by the act which manifests the actor's culpable mental state. Husak does not indicate explicitly whether the principle contains this requirement, but seems to imply it does not. ${ }^{67}$ Assuming it does not, the principle would imply that a person who attempts murder in the morning and accidentally causes a death in the evening should be punished as a murderer. Such a person would have acted with the same culpability and caused the same harm that day as a person who committed murder that day. Taken to an extreme, this approach would warrant the criminal justice system's determining penalties by surveying the total moral reprehensibility of a person's intentions over her lifetime and com-

55. For a hypothetical involving gun possession and bigamy, see RoLuIN M. PERKINS \& RoNald N. BOYCE, CRIMINAL LAW 922 (3d ed. 1982).

56. See MODEL PENAL CoDE $\S 2.03(2)$ (requiring that intent be transferred only where the harm caused is to a "different person or different property" from that intended). The classic common law cases are Faulkner (intent to steal which led to burning of ship not transferred to support liability for arson), and Pembliton (intent to hit person with stone which led to property damage not transferred to support liability for malicious damage to property). See supra notes 30-31.

57. See Husak, supra note 9 , at 96 (suggesting principle would punish as murderer a person who wounded his victim, $V$, and later, mistakenly thinking $V$ dead, disposed of $V$ in manner that caused $V$ 's death). 
paring them with the total harms caused over her lifetime. This approach, perhaps reminiscent of inquiries at St. Peter's Gate, seems wholly foreign to our moral practices.

Finally, the principle is too broad because it would seem to allow unintentionally caused benefits to become relevant for punishment. Under the principle of proportionate sentences, culpability and harm determine punishment. Culpability, as the term is ordinarily understood, is a function of the net consequences intended. If a person in acting intends to cause consequences that are harmful and consequences that produce a greater benefit for society, she will not be morally culpable and will have an affirmative criminal defense. ${ }^{68}$ Likewise, it seems to follow that harm should be a function of the beneficial as well as the harmful consequences of an act. To slightly vary the earlier School Children Case, imagine that Art shoots at Ben, kills him, and the bullet continues to kill the wild bear that was about to kill one school child, thereby saving a life. In contrast, Aaron shoots at Bob and misses, hitting nothing. Here, Art and Aaron have acted with the same culpability (each intended to kill one person) and caused the same net harm (zero). The principle of proportionate sentences would thus require that they receive the same punishments. As discussed earlier, ${ }^{59}$ this result conflicts with the law of most jurisdictions. In most jurisdictions, while Aaron would be liable for only attempted murder, Art would be liable for murder. The fortuitous saving of the school child would not be counted in Art's favor because it was unintended. Although this argument does not demonstrate that the principle of proportionate sentences is morally unsound, it at least shows that its soundness must be argued for and cannot rest on its alleged consistency with widely established moral practices.

The various types of overbreadth described above might be thought to be curable by amending the principle to inEvils).

58. See, e.g., Model Penal CODE $§ 3.02$ (Justification Generally: Choice of

59. See supra notes $46-47$ and accompanying text. 
troduce restrictions for each of the areas of overbreadth. If more areas are identified, more restrictions may be introduced. Such a strategy, however, would result in a moral theory with an unappealing ad hoc form. What is missing from the theory of proportionate sentences is not a variety of independent restrictions, but a single one: the Concurrence Principle.

This point leads to my second criticism of the principle of proportionate sentences. By failing to incorporate the Concurrence Principle, the principle of proportionate sentences fails to account for our retributivist intuitions in a satisfying manner. TI is a retributivist doctrine. Utilitarians have little use for TI because of the weak correlation, if any, between the relatively subtle psychological factors triggering the doctrine and the relatively small punishment increments it authorizes on one hand and future net social welfare on the other. ${ }^{60}$ Moreover, TI is an objective retributive doctrine. ${ }^{61}$ According to subjective retributivist doctrines, only the actor's subjective state is relevant to her desert. Failed and successful attempts are treated alike. In contrast, under objective retributivism, results-such as the killing of an unintended victim-may matter. Objective retributivism appears more consistent with existing legal

60. Those with utilitarian leanings have a hard enough to time trying justify the more straightforward and significant disparity between the penalties for completed offences and failed attempts. For a reasonably complete attempt to analyze the economic efficiency of the disparity, see Steven Shavell, Deterrence and the Punishment of Attempts, 19 J. LEGAL STUD. 435 (1990).

61. Subjective retributivists tend to oppose TI on the ground that the chance killing of an unintended victim should not be relevant to punishment. See A.J. Ashworth, Transferred Malice and Punishment for Unforeseen Consequences, in RESHAPING THE CRIMINAL LAW 67, 94 (P.R. Glazebrook ed., 1978) (stating that the proper charge for an unintended killing in the course of an attempted murder is attempted murder). Subjective retributivists object to the current practice of imposing greater penalties for completed crimes than unsuccessful attempts. TI has the effect of treating accidentally completed crimes as instances of the former class. A subjective retributivist would be in favor of TI only if she believed that by and large the actual penalties for completed offenses were closer to the appropriate level, as judged by subjective retributivism, than those for failed attempts. Thus, a subjective retributivist might approve of TI on contingent grounds. 
practice $^{62}$ and common moral intuitions than subjective retributivism. ${ }^{.3}$ Nevertheless, objective retributivism has come under sharp attack from subjective retributivists. ${ }^{\text {s. }}$ Although they may comfortably point to the raw moral data of intuitions and practice that supports their position, objective retributivists have been hard pressed to explain why, as a theoretical matter, results should matter. The principle of proportionate sentencing is woefully unhelpful in this regard. According to the principle, culpability and harm, specifically the harm proximately caused by the actor, simply are the two variables relevant to desert. No clue is given about what these variables might have in common that make them the unique variables determining desert or what their relationship might be. Admittedly, explanations must end somewhere, and Husak may argue that with the principle of proportionate sentences we have hit moral bedrock. Nevertheless, the principle's two-valued formula, in simply and starkly positing the relevance of culpability and caused harm, lacks the theoretic coherence that is a virtue in a moral theory.

The principle of proportionate sentences would be strengthened if supplemented with the Concurrence Principle. In its supplemented form, the principle of proportionate sentences would provide that an actor's punishment is a function of culpability and resulting harm so long as the harm was intended (or known, risked or negligently ignored). To be relevant then, the harm must be the right sort of harm, where the right sort is determined by the nature of the actor's culpability. In a nutshell, desert in

62. See supra note 22 and accompanying text (completed offenses punished more harshly than attempts).

63. See, e.g., GEORGE P. FLeTCHER, A CRIME OF SELF-DEFENSE 63-83 (1988); Michael S. Moore, The Independent Moral Significance of Wrongdoing, $5 \mathrm{~J}$. CONTEMP. LEGAL ISSUES 237 (1994).

64. See, e.g., Larry Alexander, Crime and Culpability, 5 J. CoNTEMP. LEGAL Issues 1 (1994); Sanford Kadish, The Criminal Law and the Luck of the Draw, 84 J. Crm. L. \& CrIminology 679 (1994); Stephen J. Schulhofer, Harm and Punishment: A Critique of Emphasis on the Results of Conduct in the Criminal Law, 122 U. PA. L. REv. 1497 (1974). 
the supplemented theory would go from being a matter of culpability and harm to a matter of culpability for harm. The two variables, formerly unrelated, are now connected within the theory. One advantage of such a supplemented theory is that some explanation can be given for why results matter for punishment. Results matter because the actor is being held responsible for them. Of course, under Husak's theory, it could be said that an actor is punished for being culpable and for causing harm. This formulation, however, suggests that relation of harm and culpability should be additive: the more of one or the other, the more punishment deserved. The fact that harm and culpability can each act as ceilings on desert is better understood by conceiving of culpability as playing an attributive role: without enough culpability, harm cannot be attributed; and without enough harm there is nothing to attribute.

Under an attributive conception of desert, culpability now fits the harm in a matter that precisely mirrors the relation between punishment and the conditions of punishment. Under retributive theories of punishment, if a person commits a murder, he should be punished for that murder. ${ }^{65}$ Justice is not served if the murderer, years later, is convicted of an unrelated murder that he did not commit. Just as there should be a concurrence between crime and punishment, so there should be a concurrence between culpability and harm. We may thus say that a person should be punished for being culpable for a harm.

\section{Other Mens Reas}

Consideration of mens reas other than intent offers a useful perspective on TI. Model Penal Code § 2.03 does not substantively distinguish between purpose, knowledge, recklessness, and negligence, allowing all to be "transferred" in like manner. It seems fair to presume that the validity of such transfers should stand or fall together.

65. For criticism of the expression "punishment for," see Joel Feinberg, Equal Puinishment for Failed Attempts, 37 ARIZ. L. REV. 117, 123 n.13 (1995). 
One consideration supporting this presumption is illustrated by section 2.03 itself. The attribution of a result to a person is equally a matter of causal connection to, and culpable attitude toward, the result. ${ }^{66}$ Section 2.03 establishes the same requirement of proximate causation for all four of the Model Penal Code's mens reas. ${ }^{67}$ This invariance is found in existing criminal and tort systems. A unitary set of standards across mens reas for imputing causal responsibility suggests a unitary set of standards for determining the attitudinal component of attribution. The permissibility or impermissibility of transference is part of this latter set of standards. ${ }^{68}$

\section{Knowledge}

Knowledge provides perhaps the clearest example of a case where, at least by the standards of ordinary language, transference does not work. Imagine that in the Basic Case $A$ is very sure that he will hit $B$ because $A$ has consistently hit targets at similar distances under similar conditions. $A$ fires, and having fired, immediately turns to run before noticing that not $B$, but $\mathrm{C}$ has been hit and has fallen to the ground dead. Based on his experience, $A$ at this time justifiably believes that he has killed someone. Furthermore, $A$ 's belief that he has killed someone is correct. Does $A$, however, know he has killed someone? Intuitively, we would say no-A's belief that he killed someone turned out to be true in the wrong way, not in the way he thought it would be

66. See FLETCHER, supra note 44 , at $491-92$ (describing causation as "objective attribution" and factors relation to culpability as "subjective attribution").

67. With respect to strict liability offenses, the Model Penal Code requires that the result be the "probable consequence" of the actor's conduct. MODEL PENAL CODE § 2.03(4). Although the change in terminology from the "too remote or accidental" standard of subsections 2.03(2) and (3) is not explained, the commentaries give no indication that a substantive change is intended. $I d$. at cmt. 4, 264-67.

68. Tort law applies TI to intentional torts, but not to negligent torts. This variance, however, seems more the product of the divergent historical roots of intentional and negligent torts than of any theoretical distinction between them. See Prosser, supra note 4, at 655-56, 662 (TI developed from and is limited to torts originating in action on trespass). 
true, but in a merely fortuitous way. ${ }^{69}$ Insofar as we believe that knowingly causing a harmful state of affairs should be moral grounds for punishment, $A$ should not be punished on these grounds because knowledge is not subject to transference.

The force of the prior analysis of transferred knowledge is admittedly diminished when the moral significance of knowledge is questioned. Often knowledge and responsibility are related. A claim of knowledge may function as a means of taking responsibility for any reliance that may be placed on the speaker's assertion. Belief, in contrast, often acts as a qualification signaling a take-it-for-what-its-worth attitude. (Compare "I know I can get us there in time" with "I believe I can get there in time"). There need be no difference in epistemic conditions underlying appropriate assertions of knowledge or belief. Yet it is not clear that these implications of responsibility carry over to the context of desert. Although the Model Penal Code establishes knowledge as a condition of culpability, it defines it thinly to require merely a belief that is held with a high degree of confidence. ${ }^{70}$ Without further argument, it is not clear that between two actors each of whom is practically certain that he would cause harm, reduced punishment is appropriate for the actor whose belief is held without justification or otherwise lacks the usual indicia of knowledge. ${ }^{71}$

69. See Edmund L. Gettier, Is Justified True Belief Knowledge?, 23 ANalysis 121 (1963). The result might be different if the hypothetical were altered so that $B$ stood upon a very crowded street. In this case, he might believe that if by some chance he missed $B$, he would certainly hit someone else. Relying on this altered hypothetical and this supplementary belief, it might be appropriate to say that $A$, having killed $C$, knew he had killed someone.

70. MODEL PENAL CODE § 2.02(2)(b).

71. For example: Mike and Sam are both lazy campers in different forests. Each is practically certain that if he fails to extinguish his campfire, a forest fire will result. Neither does and forest fires start. Mike had good reason to hold his belief: he had made a large fire, the woods were dry, and the wind was blowing hard. Sam had no reason: none of the conditions for fires were present; Sam just is paranoid when it comes to fires. Pursuant to the M.P.C.'s definition of knowledge, each would be liable for arson by virtue of knowingly starting a fire. 


\section{Negligence}

Tort law's treatment of negligence offers a useful perspective on TI. It is commonly said that tort law does not permit negligence to be transferred. ${ }^{72}$ There is at least substantial authority, based on Justice Cardozo's majority opinion in Palsgraf, ${ }^{73}$ holding there is not. ${ }^{74}$ Mrs. Palsgraf sued a railroad company based on the failure of railroad guard to use reasonable care in helping a passenger board a train. The guard had pushed the passenger harder than necessary, thereby dislodging a package filled with fireworks that exploded and caused a scale to fall on Mrs. Palsgraf. The majority in Palsgraf denied liability based on the reasoning that the guard owed no duty to Mrs. Palsgraf not to aggressively shove the package-carrying passenger, and the guard, having breached no duty to Mrs. Palsgraf, thus could not be liable to her, nor render the railroad, as employer, vicariously liable. This view of duty pointedly contrasted with the dissent's, authored by Justice Andrews. Andrews agreed with Cardozo that to state a claim in negligence, Mrs. Palsgraf must assert that a duty to her had been breached. ${ }^{75}$ Andrews, however, asserted that the guard owed a duty to "the world at large" not to jostle the passenger. ${ }^{76}$ When he did so, he breached that duty to everyone, including Mrs. Palsgraf. For Andrews, the only open ques-

72. Prosser, supra note 4, at 662 ('The attempt to extend the 'transfer' to negligence met defeat, apparently final, in the Palsgraf case."); see also Moore, supra note 9 , at 286 n.46 (noting tension between TI and jurisdictions following Palsgraf).

73. Palsgraf v. Long Island R.R. Co., 162 N.E. 99 (N.Y. 1928).

74. See W. PAGE KEETON ET AL., PROSSER AND KEETON ON THE LAW OF TORTS 286, 286 n.48, 288 (5th ed. 1984) (noting majority of jurisdictions accept Palsgraf rule and trend is in its favor); 3 FOWLER V. HARPER, ET AL., THE LAW OF TORTS 655 (2d ed. 1986) (noting Palsgraf view is "prevailing"); B. MCMAHON \& W. BINCHY, IRISH LAW OF TORTS 98-100 (2d ed. 1990) ("After some uncertainty, the view has prevailed throughout the common law world that the plaintiff must show that the defendant was in breach of his duty to him and [not to another]").

75. Palsgraf, 162 N.E. at 103.

76. See id. ("Every one owes to the world at large a duty of refraining from those acts that may unreasonably threaten the safety of others .... There needs to be a duty to the one complaining, but this is not a duty to a particular individual because as to him harm might be expected"). 
tion was causation. ${ }^{\text {n }}$ Cardozo's opinion constitutes a rejection of transferred negligence because it held that duties are person-specific and cannot be "transferred" to even proximately injured victims. Cardozo's opinion has been criticized for not addressing questions of "social policy." But perhaps the opinion is not wholly arbitrary and rests, if not on policy, on a modicum of principle.

I believe Cardozo's conception of duty is more coherent than Andrews'. Three facts about the duty of care support the view that duties run to individuals, not the world as a whole (or, more plausibly, to the actor's community). First, duties seem to arise from characteristics that are features of individuals, not communities. $D$ has a duty not to place $P$ at risk unreasonably, we might explain, because $P$ possesses feelings, life plans, moral convictions, rationality, etc. These characteristics are not the type that communities, as opposed to their members, may claim. Let us therefore construe Andrews to assert that duties run to the members of a community as a whole. Second, if Andrews is so construed, his position seems to imply that the strength of the duty of care varies with the number of persons in the community. Just as an actor has a greater obligation to keep a single promise (e.g., "T shall never drive over 70 m.p.h.") if it is made to each member of a large group than if it is made to each member of a small group, so an actor would have a greater obligation to act with reasonable care if in acting carelessly he thereby breached a duty to each member of a large community than if he thereby breached a duty to each member of a small community. This conclusion is implausible. Persons in larger communities may have to act with more care or act

77. Such situations, where the plaintiff is unforeseeable, but there is proximate causation, as well as the converse situations, are possible. For example, $A$, who reasonably believes that there is absolutely no chance his gun is loaded, pulls the trigger while directing the gun toward $B$. In fact, the gun is loaded and $B$ is killed. Proximate causation, but no negligence. Or, $A$ unreasonably believes that there is no chance that the gun is loaded and pulls the triggers while directing the gun toward $B$. The bullet misses, $B$ is startled, runs away and is hit by a lightning bolt. Negligence without proximate causation.

78. See KEETON ET AL., supra note 74, at 287-88. 
with care more often (because of greater community density), but, in any given situation, they have no greater obligation to act with the care requisite for that situation. Third, if $D$ 's acts place $P$ at risk unreasonably, as a general matter, only $P$ will be actually harmed and only rarely, if ever, will all the members of the community be. Because $P$ is the principal beneficiary of $D$ 's complying with the duty, we should describe the duty as a duty to $P$, not to the community at large. ${ }^{79}$

Even if Cardozo's view of duties makes sense for torts, should it be "transferred" to the criminal law? The relation between tort and criminal law is admittedly controversial. ${ }^{80}$ On one hand, tort and criminal law seem to use divergent conceptual frameworks and vocabularies. In tort law, duty and breach are primary concepts, and harm becomes relevant only at the stage of relief. In criminal law, conduct ("actus reus"), culpability ("mens rea") and resultant harm are the organizing categories. Criminal law is described as public law, tort as private law. In tort law, the defendant must be a particularized private entity; in criminal law, the moving party is the state. Following this line of argument, Cardozo's conclusions concerning transferred negligence may seem to carry little weight for criminal law. ${ }^{81}$ On the other hand, it seems that certain features of the criminal law imply features of tort law, although not vice-versa. For

79. Not every duty must be person-specific like the duty of care. $A^{\prime}$ s duty to obey the law, for example, might be thought to flow from the fact that $A$, through the course of his life, has accepted benefits from society as a whole, produced by society as a whole. Furthermore, breaking the law might be thought to incite lawlessness and social instability generally and so to injure society as a whole. Under these assumptions, the duty to obey the law arguably would run to, if not the world at large, at least $A^{\prime}$ 's society generally. Duties of the type generally enforced by the criminal law, such as the duty not to take a life, appear to be person-specific like the duty of care.

For a different and somewhat more elaborate argument in support of Cardozo's view of tort duties, see ERNEST J. WEINRIB, THE IDEA OF PRIVATE LAW 158-64 (1995).

80. See generally The Intersection of Tort and Criminal Law, 76 B.U. L. REV 1 (1996) (symposium on intersection of tort and criminal law).

81. But cf. Ritz, supra note 2 (arguing that the criminal law should follow Palsgraf and reject TI). 
example, if an activity is criminal, it generally gives rise to liability in tort. ${ }^{82}$ It seems strange that someone could be jailed for injuring you, but not have to compensate you for those injuries. Following this line of argument, it would seem strange to jail a person based on his injuring an unforeseen victim under TI where the victim would be precluded under tort law (à la Cardozo) from obtaining compensation for that injury. Indeed, the impetus for allowing transference in tort law would seem to be much stronger than in criminal law. In criminal law, even in the absence of TI, significant penalties may be imposed on the wrongdoer based on his recklessness or his failed attempt. In tort, in contrast, without transference an unforeseeable victim may be left wholly uncompensated. The "gap" for TI to fill is much greater in tort law. Yet tort law resists the impulse.

I want to suggest a simple relationship between tort and criminal law. Tort and criminal law should be understood as pursuing different visions of justice in response to the same underlying phenomena: wrongdoing. Wrongdoing, in criminal law, as much as tort law, should be understood as relative to a victim. Talk of crime as wrongdoing against "the public" or "the King's peace," I take to be reducible to wrongs against particular, if sometimes unidentifiable, members of the public. Only persons have rights so important that their violation might trigger penalties of the severity commonly imposed by the criminal law. In the face of wrongdoing to persons, tort law is concerned essentially with corrective justice, criminal law essentially with retributive justice. ${ }^{83}$ Reliance on these different norms explains the different litigation structures of tort and criminal law. Corrective justice requires a wrongdoer and a victim to be participants in the proceeding because the relative posi-

82. Unsuccessful attempts are the only major category of criminal offenses that do not generate tort liability. Unsuccessful attempts, however, are not true exceptions to the generalization that criminal liability implies tort liability because in cases of unsuccessful attempts, there is no injury to compensate for.

83. Punitive damages and forfeiture may represent limited exceptions to this generalization. 
tion of each has been altered by the wrongdoing. ${ }^{84}$ Retributive justice merely requires the wrongdoer and a neutral party to impose the punishment. These different remedial structures, rather the nature of the underlying wrongdoing, explain the public and private labelings of criminal and tort law respectively. If, as I have argued above, there is good reason from a tort perspective not to view a would-be tortfeasor as a wrongdoer with respect to an unforeseen and unintended victim, then the same should hold for the criminal law. Returning to the Basic Case, because $A$ in harming $C$ did not wrong $C$, neither a corrective nor a retributive response is triggered by the harm to $C$. The harm becomes legally irrelevant. Where there is no underlying wrongdoing to respond to, tort and criminal law must equally stay their hands and, to the extent justified by their different ideals of justice, act only based on the wrong and harm to $B$.

\section{CONCLUSION}

This article advanced the doctrine of transferred intent as a vehicle for inquiring into the nature of criminal culpability. In considering the moral soundness of treating one who harms an accidental victim like one who harms an intended victim, we have been led to examine the distinction between accidents and mistakes, the nature of intentions, the requirement of concurrence, the structure of duty, and the relation of tort and criminal law. The goal of the inquiry was to achieve an improved understanding of the moral basis of the criminal law generally. I have suggested that the criminal law should be understood, at core, as punishing actors for causing harms that were strictly intended or to which lower levels of culpability apply. This understanding implies the rejection of TI.

84. See Jules L. Coleman, The Structure of Tort Law, 97 YALE L.J. 1233, 1239 (1988) (discussing the relation of tort law's substantive goals and its litigation structure). 
The conception of the criminal law set forth above is undoubtedly incomplete. I have not addressed how it might be revised-as it undoubtedly must be to some degree-in light of considerations of practical administration and competing social values. Furthermore, I have largely assumed the validity of an objective, or result-oriented, form of retributivism. The availability of a more compelling explanation of why results matter morally would obviously aid in deciding what results matter and, in particular, whether derivatively intended harms to unintended victims matter. The lack of such an explanation, however, need not bar useful theorizing concerning significant issues that surround and inform the moral foundations of the criminal law. Or, at least, so I hoped to have shown. 